\title{
PUBLIC PERCEPTIONS OF JUDICIAL DECISIONS ON ELECTION DISPUTES The Case of the 2007 General Election in Nigeria
}

\section{Emmanuel O Ojo}

\author{
Dr Emmanuel O Ojo is Senior Lecturer in the Department of \\ Political Science at the University of Ilorin, Nigeria \\ e-mail: eojo12000@yahoo.com
}

\begin{abstract}
In a plural and deeply divided society like that in Nigeria post-election disputes are a recurring problem and if care is not taken in their resolution may exacerbate the problems of national integration. Elections do not only perform the function of elite recruitment into public office but are a mechanism for national integration. In a heterogeneous society like that in Nigeria if post-election conflict is not handled with the required neutrality the election suffers enormously from a credibility crisis. It is against this background that this article examines the role of the judiciary and its impartiality in resolving election-related conflicts arising out of Nigeria's 2007 general elections. It infers that, in a number of cases, the public perceived judicial officers to have compromised themselves. No doubt this compounded the problem of integrating Nigeria's disparate ethnic groups and, at the same time, whittled down the confidence of members of the public in the capacity of the judiciary to be an impartial arbiter. The article recommends training and retraining for judges in the interests of both national integration and democratic sustenance.
\end{abstract}

\section{INTRODUCTION}

There is no doubt that the judiciary is a cardinal institution in an established democracy. This is not unconnected with the fact that a constitutional government must, in part, be a judicial government (Hague \& Harrop 1990, p 279). The Constitution vests the judiciary, as the third estate of the realm, inter alia, with the power to interpret and apply all laws relating to both criminal and civil matters and to disputes between individuals and groups and between individuals and political authorities as well as between political authorities in a parallel 
relationship or in a vertical relationship such as between a state and the federal government in a federal system (Awa 1996, p 8). Thus, it is the guardian of the rule of law and the upholder of justice, fair play and equity. For this reason, in all Nigeria's constitutions it has enjoyed a great measure of independence from both executive and legislature, except during military interregnums.

It is imperative to note, however, that the welfare of citizens depends greatly on speedy and impartial justice. James Bryce (2006, p 613) has remarked aptly that there is no better test of the excellence of a government than the efficiency of its judicial system. The judiciary is the guardian of the rights of citizens and it protects these rights from all individual and public encroachment. If citizens feel they can rely on the certain and prompt administration of justice this maximises their liberty.

If there is no adequate provision for the administration of justice the liberty of the people is jeopardised, for there is no means of ascertaining and deciding on rights, punishing crimes or protecting the innocent from injury.

If law be dishonestly administered, the salt has lost its flavour; if it be weakly and fitfully enforced, the guarantees of order fail, for it is more by the certainty than by the severity of punishment that offenders are repressed. If the lamps of justices go out in darkness, how great is that darkness?

Bryce 2006, p 613

In ancient polities the executive and judicial functions were combined. The early monarch was the fount of justice. Later it was recognised that justice could not be secured if the judicial and executive functions were combined in one person. Historically, the concentration in the same hands of the power to interpret and administer has always been associated with tyranny (Laski 1925).

Every citizen needs complete protection against the danger of a capricious interpretation of the law. The modern state is, accordingly, inconceivable without a separate judicial organ functioning independently and impartially (Kapur 2006). In the same vein, Chaturvedi (2006, pp 160-161) noted that without an adequate mechanism for rendering justice no modern state can exist. The modern democratic state assures the people rights, generally by guaranteeing them in the constitution. However, if rights are not properly safeguarded they remain only on paper (Chaturvedi 2006). Hence, members of election petition tribunals are expected to be independent and impartial.

In view of the above, the judiciary is generally regarded as a catalyst for both democratic transition and sustenance (see Ojo 2006; Alabi 2002). But in its bid to fulfil this role the judiciary in Nigeria suffers from serious limitations, the 
most chronic of which is corruption (Davies 2003), as will be shown below. The thrust of this article, therefore, is an in depth discussion of public perceptions of judicial decisions relating to the 2007 general elections.

The article is divided into a number of sections. The next section dwells on the conceptualisation of public perception to avert misunderstanding. The third attempts a survey of election petitions across the six geopolitical zones of the country, while part four gauges public perceptions of the tribunals in the light of their integrity and the length of time they have taken to dispense justice. The inference drawn is that there is a need to amend the Electoral Act of 2006 to enhance the rapid dispensation of justice, while the National Judicial Council should be enabled to handle cases of corruption against any erring judge.

\section{CONCEPTUALISING PUBLIC PERCEPTION}

... the general purpose of ... a study (literature review) brings the reader to date in the previous research in the area, pointing to general agreements and disagreements among the previous researches ... carefully review the studies that led to the acceptance of those ideas ...

Babbie 1998

This section takes its cue from the above premise. Without necessarily defining them, for the purpose of this study we intend to properly conceptualise public perceptions. Public opinion as a term in its contemporary sense was first used in the writings of Machiavelli when he suggested that a wise prince will not ignore public opinion about such matters as the distribution of offices. In his social contract Rousseau, too, dealt with public opinion as it relates to the democratic process. Many contemporary writers have also used the term. Yet its precise meaning is often unclear as its usage varies with each writer (Kousoulas 1982, pp 85-86). Put differently, the term does not lend itself to a precise definition despite the abundant literature it has inspired.

The precise meaning of the word 'public' or 'individual' is uncertain and has long been debated and public opinion creates quite a different type of confusion, a confusion which, according to Benson (1967/8, p 522), 'stems from the concept's moral implications'. In an attempt to emphasise the moral quality of opinion most scholars have restricted the meaning of the term 'public opinion' to collections of individual opinion measuring up to a 'certain standard of excellence'. However, what that standard is has never been ascertained. In a similar vein, Sanerwein (1983, p 29) has maintained that 'it is rather an exaggeration to pretend that there exists at the present time a "public opinion" in the intellectual sense, outside of 
the elite'. The problem with this position is that it renders the masses politically irrelevant.

Another source of conceptual confusion is the tendency of some theorists to equate opinion with attitude. An 'opinion' usually connotes a position on specific political issues, while an 'attitude' represents a persistent general orientation towards some individuals, groups, institutions or processes, which does not necessarily result in a specific position on specific issues (Rodee, cited in Ojo 2004).

Although attitudes may help to shape opinion and each may be used as an indicator of the other, 'the complex inter-relationships between opinions and attitudes can perhaps be uncovered and disentangled after painstaking investigation, they cannot automatically be assumed, a priori, to take a particular form' (Newcombe, cited in Ojo 2004). Idang (1973, p 78) posits that people who hold similar attitudes to a particular political issue, for instance, may nevertheless have contradictory opinions on a specific public policy dealing with the issue. It is instructive to note that distinguishing between 'opinion' and 'attitude' is therefore more than a mere semantic exercise. Nevertheless, V O Key (1961, p 14) has offered a relatively popular definition of public opinion as 'those opinions held by private persons which governments find prudent to heed'.

The problem with this definition is the word 'heed'. How does one infer that an opinion expressed but not heeded by the government is not prudent? Indeed, the definition is too broad, as the barometer for determining prudence is not only obscure but vague. For Hennessy (1970, p 20), 'public opinion is the complex of beliefs expressed by a significant number of persons on an issue of public importance'. Scholars generally believe that public opinion is the collection of individual opinions on an issue of public interest and that such opinions can exercise great influence over individual and group behaviours vis-à-vis government policies.

For analytical simplicity more recent literature conceptualises public opinion as the opinion of a people, made up of different views or comments, including the sentiments of the citizenry. Some comments, says Bryce (cited in Kapur 2006, p 613)

develop more strength than others, because they have behind them large numbers or more intensity of conviction and when one is evidently the strongest, it begins to be called public opinion par excellence being taken to employ the views supposed to be held by the bulk of the people.

Public opinion is the opinion the people in general hold on questions of common 
interest at a certain time. In a perceptive work Adebayo \& Omotola (2007, p 203) state that 'an idea, a belief, or an image one has of reality as a result of how one sees or understands the reality, is coterminous with public opinion'.

The task of measuring public opinion is, therefore, a difficult one and must take cognisance of the basic attributes of a good public opinion poll. These include, apart from intensity and the social status of the respondents, the saliency of the opinion, defined in terms of its prominence or weight. Others include fluidity, that is, the adaptability of the opinion, its violability - how rapidly it changes, latency - visibility, and intensity - the strength of the opinion or the degree to which it is held (Ripley \& Slotwick 1989, pp 49-50; Adebayo \& Omotola 2007, p 204). ${ }^{1}$ These criteria provide us with the benchmark against which to assess public perceptions of election petition tribunals in relation to the 2007 general election in Nigeria.

\section{ELECTION PETITION TRIBUNALS: A SURVEY}

The 2007 general election in Nigeria was reputed to be the most litigious in the country's history. Both local and international election monitors were unanimous that the election was greatly flawed. This finding is not unconnected with the fact that the conduct of the election failed to meet the minimum internationally acceptable standards, whereas an objective electoral process must meet certain criteria (Odhiambo, 2009).

Firstly, every eligible voter must have the opportunity to participate in the process. Secondly, an independent body should conduct the elections. Thirdly, each vote must carry equal weight, that is, one-person-one-vote. Further, the process must be transparent. Moreover, the result should reflect the number of votes that have been cast. Lastly, dissatisfied candidates must be given an opportunity to challenge the results before independent courts or tribunals. The absence of these key ingredients, or their presence in haphazard manner, makes it difficult for an election to be deemed free and fair (see Omotola 2009). The absence of most of these ingredients from the 2007 general elections led to unprecedented litigation that compelled Omotola (2009) in his perceptive work to describe Nigeria as operating a 'garrison democracy'.

We now turn to a brief survey of election petitions across the geopolitical zones of the country. One major observable phenomenon is that no zone of the

1 For standards, see International Convention on Civil and Political Rights, GA Res 2200 (XXI) UN GAOR, 21st Sesa Supp No 16 cat 52, UN Doc A/ 6316 (1966) 999 UNTS 171 (entered into force 23 March 1977) (ICCPR), Arts 2(3), Universal Declaration of Human Rights, UNGA Res 217 A. GAOR 3rd Sess, 183 plan Mtg at22, UN Doc A/810 (1948) *UNHR), Arts 8 and 21. Also cited in Odhiambo 2009, p128. 
country was immune from litigation after the conduct of the elections, which triggered off a serious succession crisis (see Ojo 2007, pp 14-32).

Beginning in the South-West zone, which comprises six states, Ademola Adeoye of the National Democratic Party (NDP), Muiz Akande of the People's Redemption Party (PRP) and Senator Isiaka Abiola Ajimobi of the All Nigeria Peoples Party (ANPP) contested the election of Governor Adebayo Alao Akala in Oyo State. However, the real legal fireworks erupted between Akala and Ajimobi. After ten months of legal battle the election petition tribunal sitting in Ibadan, Oyo State, gave its judgement on the petitions challenging the declared victory of Akala (The Guardian, 18 March 2008). Despite the lengthy litigation process the judgement did not go down well with the majority of voters in the state.

In Lagos State, Jimi Agbaje of the Democratic Peoples Alliance (DPA) also appeared before the tribunal because his picture was not on the ballot papers used in the poll. It did not take much time, however, before the tribunal validated the victory of the governor, Babatunde Fashola (Tell, 28 May 2007, p 27).

In Ekiti State, Kayode Fayemi, gubernatorial candidate for the Action Congress (AC), claimed that the Independent National Electoral Commission (INEC) erred in declaring Segun Oni of the People's Democratic Party (PDP), governor-elect, alleging that the election was fraught with irregularities and manipulation. The election petition tribunal agreed with the $\mathrm{AC}$ candidate and nullified the election, asking for a rerun, which again returned the PDP candidate. The ding-dong battle continues, with the AC candidate still asking for justice some three years after the election. Eventually Oni's victory was reversed.

In Osun State the scenario was dramatic. Rauf Aregbesola, the AC's gubernatorial candidate, in a 108 000-page petition, alleged massive rigging of the polls. His lawyers submitted to the tribunal six large bags containing the statements of witnesses and other documents in respect of their case. During the trial it was leaked to the public that the tribunal, led by Justice T S Naron, had compromised itself. An examination of Justice Naron's telephone records revealed that he had been in constant communication with Governor Olagunsoye Oyinlola's lawyer.

Virtually all the news media were awash with the report. When the tribunal delivered its judgement it was already tainted with bias in the eyes of the public. Predictably, the judgement favoured Oyinlola. Aregbesola appealed and the AC and its candidate petitioned the National Judicial Council (NJC) on the unethical conduct of the judge. The Court of Appeal ordered a retrial of the case ab initio. The litigation was resolved some three years after the election in favour of the AC candidate. The judgement was well received by the public.

In Ogun state Governor Gbenga Daniel of the PDP faced two aggrieved contestants - Dipo Dina of the AC and Amosun Kunle of the ANPP. The trial and 
retrial dragged on until 2010, when Daniel's election was validated by the Court of Appeal sitting in Ibadan, Oyo State.

In Ondo State, Segun Mimiko of the Labour Party (LP) challenged Governor Olusegun Agagu of the PDP. The trial, which began in October 2007, ran until 2009, when Agagu was removed by the Court of Appeal sitting in Benin, capital of Edo State. This judgement, too, was considered to be courageous.

There were similar cases in the South-South zone of the country, which comprises six states. Adams Oshiomhole formally assumed office as governor of Edo State on 12 November 2008. His journey to Government House was made possible by the Court of Appeal's Benin Division, which upheld the 20 March 2008 verdict of the State Election Petitions Tribunal that he and not Oserheimen Osunbor had won the April 2007 gubernatorial election (The Punch, 13 November 2008, p 7).

The tribunal received 56 petitions and decided all the cases in favour of the respondents (Nigerian Tribune, 5 May 2008, p 6). For record purposes one may note that, after a long-drawn-out legal battle the Election Petition Tribunal in Asaba threw out the petition filed by Chief Great Ogboru (DPP) against the election of Governor Emmanuel Uduaghan of Delta State on the grounds that Ogboru had failed to comply with the statutory conditions for filing such a petition (Nigerian Tribune, 5 May 2008, p 6).

In the same zone the Court of Appeal, sitting in Calabar, Cross River State, upheld the election of Governor Godswill Akpabio of Akwa Ibom State, dismissing the appeal brought by the $\mathrm{AC}^{\prime} \mathrm{s}$ gubernatorial candidate, James Iniama (The Guardian, 25 March 2008, p 4).

In the South-East zone, which comprises five states, the Court of Appeal in Port-Harcourt dismissed the appeals against the elections of Governor Ikedi Ohiakim of Imo State and his counterpart in Abia State, Theodore Orji. The petition against Ohiakim, which was filed by Chief Martins Agbaso of the All People's Grand Alliance (APGA), was dismissed in a leading judgement by Justice O Ariola (The Punch, 25 April 2008, p 1).

In North-Central zone, which comprises six states including the Federal Capital Territory (FCT), Gbenga Olawepo of the Democratic People's Party (DPP) in a lengthy process challenged the victory of Governor Bukola Saraki of the PDP in Kwara State (Nigerian Tribune, 21 February 2008, p 8). The battles of the governorship candidates did not divert those of aggrieved candidates in the April elections for the Senate and the House of Representatives.

Also in Kwara State, for example, Biliki Sulu Gambari, the AC's National Assembly candidate, claimed to have been denied justice and wanted the tribunal to annul Gbemisola Saraki-Fowora's victory (Tell, 28 May 2007, p 27). In Benue State the election petitions tribunal annulled David Mark's election as senator 
representing the Benue South Senatorial District after Usman Abubakar, candidate for the ANPP, contested Mark's victory in Okpowu and Agatu, two of the nine local government areas that make up the senatorial district, where he claimed the results were cancelled due to electoral malpractices (Tell, 10 March 2008, p 21). Mark appealed the judgement and his election was later validated, but his victory was seen as the result of interference by the powers-that-be.

The Kaduna State elections petition tribunal received about 19 petitions from aggrieved candidates in the 2007 polls (The Guardian, 25 May 2007). Also in the North-West zone, Aliyu Wamakko's election as governor of Sokoto State was nullified by the Court of Appeal sitting in Kaduna on the grounds of improper nomination - the person who had won the party primaries was another person altogether, but Wamakko was fielded as the party's nominee, which contravenes the provisions of the Electoral Act of 2006. While Wamakko lost his seat his counterpart in nearby Kebbi State, Usman Bakingiri, retained his.

In Adamawa State, which falls under the North-East zone, the Court of Appeal ordered a fresh gubernatorial election (The Guardian, 11 March 2008, p 9).

The presidential election, too, did not pass unchallenged. General Muhammadu Buhari of the ANPP and Atiku Abubakar of the AC challenged the victory of President Umaru Yar'Adua of the PDP and it was about eight months before the presidential election petition tribunal validated the victory of Yar' Adua as president and Goodluck Jonathan as vice-president.

There were many more cases of challenges, which will not be covered in this article, but there is no doubt that the 2007 general election was the most fiercely contested in Nigeria's history.

\section{PUBLIC PERCEPTIONS OF THE ELECTION PETITION TRIBUNALS}

A number of observations can be made about they way the above cases were handled and the nature of the judgements. The salient ones made by members of the public revolve around three key issues. First, as correctly observed by Mohammed Haruna (The Nation, 5 March 2008, p 48), the courts not only refused to take judicial notice of '... these and other attempts by the authorities to fix the elections, they dismissed the opposition's petitions as "miniature complaints"! Yet, there were fundamental flaws in the very foundation of the elections.'

This perception is probably a response to the handling of the gubernatorial election petition in Oyo State. During the conduct of the election there was unprecedented violence in the state. During the tribunal's sitting in Ibadan 20 guns 125 cartridges, 41 cutlasses, one axe, one iron glove, six bundles of charms and amulets, 72 voters' cards and ballot boxes were among exhibits tendered by 
Taiwo Lakenu, an assistant commissioner of police (Nigerian Tribune, 6 September 2007, p 1).

Ironically, despite all this evidence, the tribunal ruled that the petitioner Senator Isiaka Ajimobi, the ANPP gubernatorial candidate in the election - had not proved beyond reasonable doubt that the election violated the provisions of the Electoral Act, particularly the provisions of s 136, which concerned violence. ${ }^{2}$

In addition, while the cases in Oyo and Edo states were similar, the judgements were quite different, with the result in Edo State being overturned while that in Oyo State was upheld.

Another factor that must influence public perceptions is the allegations of rampant corruption against tribunal and appeal panelists. Newspapers and news magazines were full of shocking details of attempted and even successful bribery of judicial officers presiding over election matters (The Guardian, 10 September 2008, p 18). Lending credence to these allegations The Punch reported that some of the election petitions tribunals might have compromised their integrity, as in two states a whopping N2.3-billion was allegedly paid to pervert justice.

Among the allegations was that about N1.5-billion had been paid into bank accounts for certain tribunal members in one of the states in the SouthSouth geopolitical zone. In addition, N800-million was allegedly paid into a bank account for tribunal members in one of the states in the North-West zone. The allegations of graft coincided with a communication from the House of Representative Committee on Justice to the Nigeria Bar Association (NBA) soliciting its partnership in maintaining the sanctity of the judicial process.

Though the states and identities of the judges involved in the scandal have not been established, according to The Punch (4 April 2008) bank statements showing how the N2.3-billion was lodged were attached as evidence to petitions sent to appropriate institutions. As though tacitly corroborating media reports of corruption the president of the Court of Appeal, Justice Usman Abdullahi, accused politicians of using various means to tilt justice in their favour.

The allegations were so rife that judges were refusing to handle election tribunal matters because of harassment by politicians. For this reason, Justice Abdullahi had to preside personally over the Court of Appeal panel that handled the Edo State governorship tussle (The Punch, 13 November 2008). There is no doubt that the Nigerian judiciary is a reflection of societal rot, whereas,

2 Section 136 (Offences on election day) sub-section (1) of the Electoral Act 2006 states that no person shall on the date in which an election is held do any of the following acts or things in a polling station or within a distance of 300 metres of a polling station:

(f) be in possession of any offensive weapon or wear any dress or have any facial decoration which in any event is calculated to intimidate voters. 
an independent and corruption-free judiciary is a sine qua non for democratic sustenance and consolidation (see Ojo 2003, pp 294-311; Davies 1990; Ojo \& Adebayo 2009, pp 1-26).

The third worrying issue to have emerged from the litigation process is not unconnected with unwarranted delays in the adjudication of cases and uncertainty about the law owing to conflicting judicial pronouncements in similar cases and in the face of similar evidence (The Guardian, 10 September 2008, p 18). It is almost beyond dispute that even the most dogged and painstaking jurist would have problems detecting and making sense of the legal reasoning behind some of the decisions by the various divisions of the Court of Appeal. There is 'neither rhythm nor rhyme to the ratio of the decisions of the appellate court' (The Guardian, 10 September 2008, p 18).

This was the case, for instance, in respect of the appeal judgements relating to the governorship elections in Sokoto and Kebbi states on the one hand and Enugu State on the other. Add to the mix the decision in the senate president's petition in Benue State. What has emerged is 'an uncomplimentary image of a Yoyo Court of Appeal' commented The Guardian (10 September 2008, p 18), adding that 'this has in turn put the judiciary on trial in the court of public opinion'.

On the other hand, the unwarranted delays in disposing of election disputes - trial and appeal - are as exasperating as they are ridiculous. It is scandalous that close to three years after the presumed winners of the May 2007 elections were sworn in, the election petitions tribunals and the courts were still inundated with petitions. The late President Yar' Adua observed that the distractions 'for smooth governance and delivery of the dividends of democracy' caused by this anomaly 'are better imagined'. He was not aware of any other country 'where litigations arising from elections drag on for years after presumed winners have been sworn in' (The Punch, 20 November 2008, p 14).

Yar' Adua regretted that, 'while the electoral law puts a firm ceiling on the period within which electoral petitions must be filed, the same law does not put a similar ceiling on when such cases must be concluded' (The Punch, 20 November 2008, p 14). Without doubt, the impact of these obvious anomalies on the nascent democratic project since 1999 is enormous. In 2003 Chris Ngige took office unlawfully as the governor of Anambra State and remained there for more than two years before the Court of Appeal invalidated his election. In Edo State Osekheimen Osunbor was installed instead of the rightful winner for more than two years before Adams Oshiomole was inaugurated in 2009. The political uncertainty, confusion and waste of public funds are unfortunate and point to the serious flaws inherent in the 2006 Electoral Act.

Yet Nigeria was once able to decide all election cases far ahead of inauguration ceremonies. For instance, s 177(3) (a) and (b) of the Electoral Decree 
No 73 of 1977 that delivered the 1979 elections provides that election petitions in respect of the office of the president and vice-president shall be completed not later than one month from the date of the election and that petitions relating to other elections must be disposed of not more than two months from the date of the elections and s 118 says 'any appeal to supreme court must be filed not later than 14 days from the date of the decisions of the election petition tribunal, and the decision of the supreme court in the appeal shall be given no later than 14 days from the date on which the appeal was filed'. The anticipated electoral reforms should take care of these problems because to allow an unelected person to stay in office even for one day is the worst form of corruption.

\section{CONCLUSION: THE WAY FORWARD}

The judiciary is long overdue for a general overhaul if it is to deliver in a democratic dispensation. Society is a mirror of the kind of judiciary it gets and with pressure on Nigeria to attain minimum international standards with regard to the conduct of elections, both the Bar and the Bench must be sanitised so that the third estate of the realm is braced for the challenge ahead. To do this, members of both the Bench and the Bar must be attuned to the reality that a corrupt judiciary cannot be a catalyst for democratic sustenance.

An ideal judiciary is one whose personnel are above board as regards moral rectitude. The strongest recommendation of this article is that government must be seen to be maintaining discipline so that judicial officers who are found to be wayward can be thrown out of the system. It is also imperative that because of the crucial role the judiciary is expected to play in administering justice, its personnel must be well remunerated to dissuade them from yielding to temptation.

The courts are in dire need of modern facilities and an environment conducive to speeding up the pace of dispensation of justice, which is currently at its lowest ebb (Ojo 2000, p 12). In the words of William Gladstone, 'justice delayed is justice denied'.

\section{- REFERENCES -}

Adebayo, P F \& J S Omotola. 2007. 'Public Perceptions of the 2007 Nigerian General Elections'. Journal of African Elections 6(2) Special Issue: Nigeria's 2007 General Elections, October.

Alabi, M O A. 2002. The Supreme Court in the Nigerian Political System (1963-1997).

Ibadan: Demyaxs Press Limited.

Awa, E. 1996. 'Democracy in Nigeria: A Political Scientist's View'. In O Oyediran 
(ed). Governance and Development in Nigeria: Essays in Honour of Prof. B.J. Dudley. Ibadan: Oyediran Consult International.

Babbie, E. 1998. The Practice of Social Research. Balmont, CA: Wadsworth Publishing Company.

Benson, L. 'An Approach to the Scientific Study of past Public Opinion'. Public Opinion Quarterly 1967 / 68, p 522.

Bryce, J. Modern Democracies. Cited in A C Kapur. 2006. Principles of Political Science.

New Delhi: S. Chand \& Company Limited.

Chaturvedi, A K. 2006. Dictionary of Political Science. Academic (India) Publishers.

Davies, A. 1990. 'The Independence of the Judiciary in Nigeria: Problems and Prospects'. African Study Monographs 10(3), February.

_. 2003 'Reflections on the Imperative of Transparency and Accountability for Good Governance'. Journal of Business and Social Sciences 8 (1\&2).

Federal Republic of Nigeria. Electoral Act 2006. Official Gazette, 22 June.

Guardian, The. 2008. 'Election Petitions and Judicial Reputation', 10 September.

Hague, R \& M Harrop. 1990. Comparative Government and Politics: An Introduction 3rd Edition. London: Macmillan.

Haruna, M. 2008. ‘People and Politics. The Nation, 5 March.

Hennessy, B C. 1970. Public Opinion. Belmont, Ca: Wadsworth.

Idang, G J. 1973. Nigeria's Internal Politics and Foreign Policy 1960-1966. Ibadan: Ibadan University Press.

Key, V O. 1961. Public Opinion and American Democracy. New York: Alfred Knopf.

Kousoulas, D G. 1982. On Government and Politics: An Introduction to Political Science. Monterey, CA: Books/Cole Publishing Company.

Laski, H J. 1925. A Grammar of Politics. Yale University Press.

Odhiambo, E. 2009. 'Consequences of a Flawed Presidential Election'. Legal Studies 29(1), March.

Ojo E O \& P F Adebayo. 2009. 'Can Nigeria's Nascent Democracy Survive?'. Journal of Sustainable Development in Africa 11(1).

Ojo, E O. 2000. 'The Judiciary, Phenomenon of Corruption and Sustenance of Democratic Values in Nigeria: A Prognosis'. Unpublished paper presented to the Faculty of Business and Social Sciences Seminar Series 1998/1999 Academic session, February.

2003. 'The Phenomenon of Corruption and the Challenges of Democratic Consolidation in Nigeria: A Prognosis'. In G Onu (ed). Corruption and Sustainable Development: The Third World Perspective. Abuja: AFRIGOV and Bookpoint Publishers Limited.

2004. 'Public Opinion and the conduct of Nigeria's Foreign Policy: Two selected case studies'. The Nigerian Journal of the Social Sciences, An Official 
Journal of the Faculty of Social Sciences, University of Ado Ekiti, Nigeria, 3(1), April.

—_. 2007. 'Editorial'. Journal of African Elections 6(2) Special Issue: Nigeria's 2007 General Elections, October.

_-_ 2007b. 'Nigeria's 2007 General Elections and the Succession Crisis: Implications for the Nascent Democracy'. Journal of African Elections 6(2). Special Issue: Nigeria's 2007 General Elections, October.

___ (ed). 2006. Challenges of Sustainable Democracy in Nigeria. Ibadan: John Archers Publishers.

Omotola, J S. 2009. 'Garrison Democracy in Nigeria: The 2007 General Elections and the Prospects of Democratic Consolidation'. Commonwealth and Comparative Politics 47(2), April.

Ripley, R B \& E E Slotwick. 1989. Readings in American Government and Politics. New York: McGraw Hall Books.

Sanerwein, J A. 1983. 'The Moulders of Public Opinion'. In Q Wright (ed). Public Opinion and World Politics. Chicago: University of Chicago Press.

\section{Newspapers}

Guardian, The, Lagos.

Nigerian Tribune, Ibadan.

Punch, The, Lagos.

Tell, Lagos. 